\title{
The Impact of Social Enterprises: A Bibliometric Analysis From 1991 to
}

\section{0}

\author{
Faraudello Alessandra ${ }^{1}$, Barreca Manuela ${ }^{2}$, Iannaci Daniel ${ }^{3} \&$ Lanzara Federica $^{3}$ \\ ${ }^{1}$ University of Eastern Piedmont - UPO, Novara, Italy \\ ${ }^{2}$ USI, Lugano, Switzerland \\ ${ }^{3}$ University of Turin, Turin, Italy \\ Correspondence: Faraudello Alessandra, University of Eastern Piedmont - UPO, Novara, Italy.
}

Received: January 2, 2021

Accepted: January 26, 2021

Online Published: March 2, 2021

doi:10.5430/ijfr.v12n3p421

URL: https://doi.org/10.5430/ijfr.v12n3p421

\begin{abstract}
The aim of this work is to provide, through a bibliometric analysis of the last 30 years of thematic literature, an overview on the contribution of social enterprises to the achievement of global goals.

A bibliometric method has been used to analyze the characteristics, citation patterns and content of 3318 documents published in international academic journals, books review and chapters, editorial material and proceedings papers.

Considering our findings, the bibliometric analysis has shown that there are journals that have had a greater production on the topic with an impact on research. Thanks to the work of the most impactful authors, it emerges that the case study is the most used method to demonstrate the centrality of social enterprises in social innovation. The analysis also shows that the centrality of the themes is linked to innovation, impact, management and performance, demonstrating the assumption that the driver of innovation in terms of social impact is given by these types of companies. The research also shows the keyword evolution through the years.

Through the coding activity, it has also been possible to demonstrate that by transposing the global sustainability objectives to the local that the more in-depth ones are addressed on the issues of sustainable economy and fair, responsible and sustainable innovation, while there is much shortcoming regarding the achievement of gender equality, sustainable water management but even more on the reduction of inequality between nations. The latter is probably conditioned by the more global target and therefore not easily approachable to social enterprises.
\end{abstract}

Research limitations/implications - The study shows a limitation, related to the adoption of the bibliometric method. However, it considers books review, chapters, papers published in international and academic journals, editorial materials, reviews and proceedings papers.

Originality/value - This research shows that the interest on SDG and social enterprises has grown continuously in the last 30 years, especially in the last 5 . The literature puts social enterprises at the center of social innovation by focusing on performance and management issues. Therefore, with the intention of mapping the studies that have been done in this regard, the study analyzed how research on local development coherence for global development has been addressed.

Keywords: social enterprise, social innovation, local innovation, performance, management, bibliometrics analysis, SDGs

\section{Introduction}

Sustainable development, particularly in the last 10 years has emerged as an influential, yet controversial, concept for business and policy. Before that period literature and interest on the specific topic was quite scarce. Among these years, however, entrepreneurship has been interpreted as the vehicle of transformation to sustainable products and processes, even if there is still uncertainty regarding the nature of entrepreneurship's role in the area of sustainability and how it may unfold. As demonstrated in a previous study, in this field, from an academic point of view, there are still gaps in our knowledge of whether and how this process will unfold. To enhance the knowledge on that topic, this paper extended the analysis of the literature evolution from 1991 until 2020. Even considering a wider period, it is 
confirmed that not many scholars have explored sustainable development from an entrepreneurship orientation (Hall, 2010).

After 2010, and specifically after 2015, several authors examined the topic and tried to fill the literature gap. In fact, in 2015 the United Nations proposed 17 Sustainable Development Goals (SDGs), which represent a clear challenge not only for national governments but also for a wide range of stakeholders (Keesstra, Bouma, Wallinga, Tittonell, Smith, Cerdà, Montanarella, Quinton, Pachepsky, van der Putten, et al. 2016), in particular for social enterprises. After the intervention of the United Nations on the SDGs fields, it is possible to observe that literature on social enterprises have had a greater production on the topic with an impact on research (P. Biancone et al. 2019a; P. P. Biancone e Radwan 2019; P. Biancone et al. 2019b; 2018; Secinaro et al. 2019; Meneguzzo 2005). Before that period, told before, the literature on the topic is quite scarce.

According with the examined literature, it is confirmed that the main players in the area of impact economy are social enterprises (Bicciato 2000; Borzaga 2002; Borzaga e Tortia 2004; Calò et al. 2018; Farmer, Hill, e Muñoz 2012). Social enterprises are the best structured companies of the whole panorama of the third sector (Zamagni, Venturi, e Rago 2015).

Facing today's social and economic challenges implies an inclusive entrepreneurial system (Zamagni, Venturi, e Rago 2015), that is, one in which social enterprises are engines of economic and social inclusion for the territories in which they operate (Giuliani et al. 2018). The phenomenon influences business extensions (Goldoff 2000; Moore, Westley, e Brodhead 2012; Moore, Westley, e Nicholls 2012; Motta, Dini, e Sartori 2017; Rehn 2008). In the research emerges that the case study is the most used method to demonstrate the centrality of social enterprises in social innovation that literature confirms (Zamagni, Venturi, e Rago 2015; Borzaga 2002; Borzaga e Tortia 2004; Fiorani, Jannelli, e Meneguzzo 2012; Mosca, Musella, e Pastore 2007). Innovation (646), performance (371), management (257) and entrepreneurship (193), are the most used keywords in those articles, demonstrating the assumption that the driver of social impact is given by these types of keywords for social enterprises.

In this work, the research focuses on the evolution of social enterprises through a bibliometric approach from 1991 to 2020. They had been analyzed the characteristics, citation patterns and content of 3318 documents published in international and academic journals, editorial materials, reviews and proceedings papers.

The aim is to demonstrate how social enterprise contributes to the achievement of sustainable goals and to crystallize the academic studies on this field and moreover to demonstrate the evolution of the perception of social enterprises in literature. This research shows how, among 30 years, the literature has put social enterprises at the center of social innovation by focusing on performance and management issues. Therefore, with the intention of mapping the studies that have been done in this regard, the paper aims to explore how research on local development coherence for global development has been addressed.

In order to explore the contents of social enterprises literature, to understand whether SDGs are also typical of the analyzed sector, as well as to understand if they have already been covered in other aspects and to track their evolution and identify the main flows of the academic sector, this work is organized as follows:

(i) Analysis of the literature;

(ii) Identification of the most influential articles;

(iii) Analysis of keywords.

The next section presents the methodology, consisting of hypotheses and basic methodology. It includes a review of what is present in the literature on the state of knowledge regarding the results on how social enterprises contribute to the achievement of SDG goals.

The third section explains the categorization of these findings. After describing the results of each method used, the fourth section outlines the implications and conclusions.

\subsection{Background}

Starting from the "Independent Group of Scientists appointed by the Secretary-General, Global Sustainable Development Report 2019: The Future is Now - Science for Achieving Sustainable Development, (United Nations, New York, 2019).", this study aims to identify how social enterprises acts in promoting the effective functioning of the SDG.

In the motivating principles of the SDGs, the Secretary-General states (United Nations, 2017, p. 2): "In adopting the 2030 Agenda for Sustainable Development, world leaders resolved to free humanity from poverty, secure a healthy 
planet for future generations, and build peaceful, inclusive societies as a foundation for ensuring lives of dignity for all [...] Our challenge now is to mobilize action that will bring these agendas meaningfully and tangibly to life. I call on Governments and stakeholders to recognize the gaps that have been identified in this report - in implementation, financing and political will - and to now join hands to fulfil this vision and keep this promise".

The 17 SDGs developed by the UN recognize and ratify the essential social, economic and environmental issues facing our society. Governments and the public sector as well as the stakeholders and the enterprises too as a whole must use the SDGs as a basis for developing the public implementation (Farneti et al. 2019). The SDGs are embedded and framed in public governance, and their realization will strongly depend on it; the formulation of the SDGs may refer to different levels of commitment, but still: public administration is everywhere in the SDGs (Bouckaert, Loretan, e Troupin 2016).

On the other hand, according to the 2015 report by Social Enterprise UK - Think Global Trade Social - social enterprises too have an important role to play in the achievement of the UN's new Sustainable Development Goals (SDGs). However, with 17 SDGs and no less than 169 associated targets, understanding how social enterprises can contribute to the achievement of these goals remains challenging. Literature is limited on that field so an important academic contribution with a deepening on that topic appears to be highly recommended in order to reach substantial progress in achieving global goals and meet the criteria of 2030 Agenda for Sustainable Development (Littlewood e Holt 2018).

\section{Methodology}

\subsection{Method}

The study was conducted in the form of bibliometric analysis. According to Verbeek, Debackere, Luwel, \& Zimmermann (2002), bibliometric analysis can be defined as follows: "Bibliometrics is the statistical analysis of scholarly communication through publications". All sources are used to perform rigorous bibliometric and network analysis (e.g., citation and citation analysis) with the function of tracing the knowledge structure of this topic.

The analysis of the network through bibliometric tools has proved useful in identifying consolidated and emerging topical areas (Aria e Cuccurullo 2017). The statistical analyses were done with the statistical software R-Studio.

\subsection{Identification of Papers}

Three thousand, three hundred and eighteen documents have been identified based on the assumptions made.

This bibliometric study focuses to be precise on certain research boundaries. The keywords to be used have been designated with an asterisk (*) to show the range of possible studies, as many existing works use slightly different keywords for the same concept, e.g. "Social Enterprise" instead of "Social Enterprise". Two classes of keywords have been selected:

1. The keywords related to the concept of social enterprise, and therefore "Social Enterprise*, to gather more existing publications on the subject; and

2. The keyword which is now one of the main focuses needed to achieve the goals set by Agenda 2030, "innovation".

A meta-search engine (Web of Science-WOS) was used in the research, which accessed the most well-known academic databases. This multidisciplinary database allows researchers to identify key articles for scientific analysis (Okoli e Schabram 2010; Webster e Watson 2002).

These results were then aggregated into a single list for comparative purposes. Articles dealing with the areas business, business finance, economics, management, public administration, social work and social issues have been included in our list. For a better search, only peer review journals have been selected. In order to answer the research question, articles published from 1991 to 2020 (July2020) have been selected. Peer-reviewed journals play a fundamental role in the dissemination of scientific knowledge, the exercise of reputation control, the recognition of intellectual property and the construction of the group's membership and identity (Whitley 2000a).

The language of publication selected is English in order to have a wider and more homogeneous overview.

The aggregation of articles over a period of these years yields data that can be processed with standard bibliometric methods (Heradio, Perez-Morago, et al. 2016; Li e Zhao 2015b; Ma et al. 2016b; Rey-Martí, Ribeiro-Soriano, e Palacios-Marqués 2016).

The above process can be summarised and represented in Figure 1 below. 


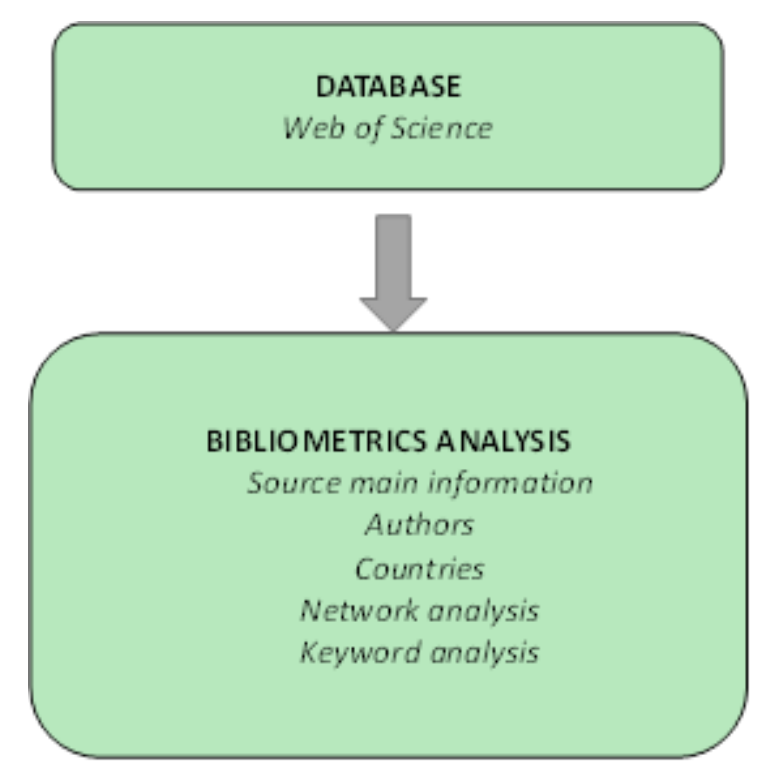

Figure 1. Methodology framework

Source: our elaboration

\section{Results and Findings}

\subsection{Publication Pattern}

During the period under review (1991-2020), the number of publications in social enterprises journals increased the production between 2015 and 2019 (2020 has just started). Scientific output started in 2001 and reached the top in 2018 (Figure 2). The data confirm what has already been said above. This field of research is continuously evolving, and the horizons are increasingly broad.
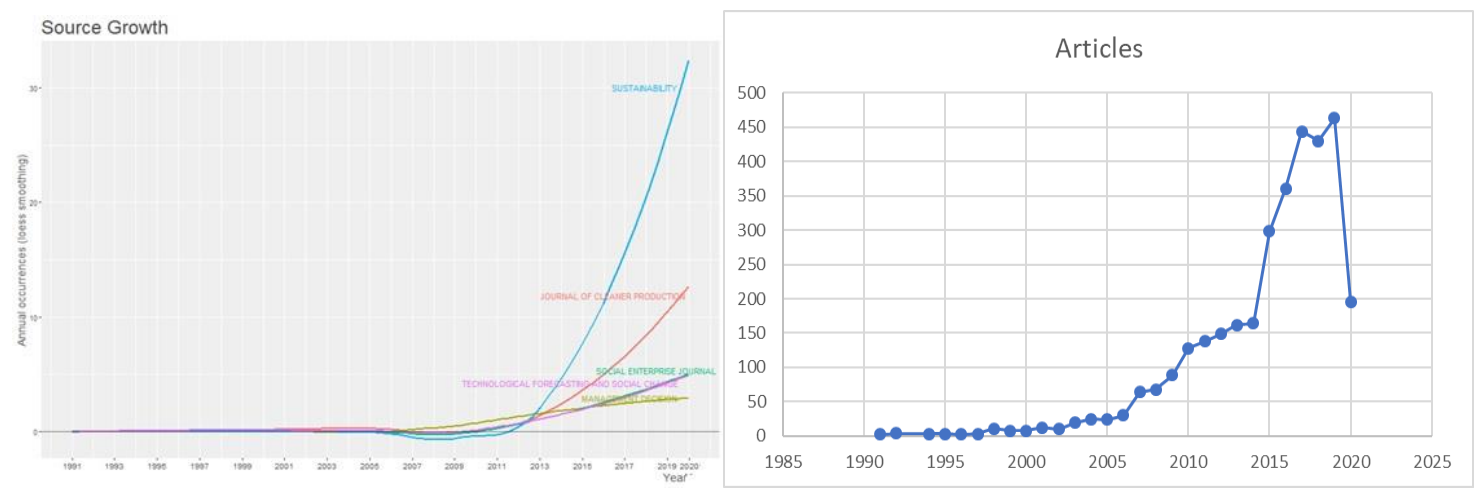

Figure 2. Articles per year

Source: our elaboration from Biblioshiny

Considering the first 20 journals that published the articles considered, the first four show a more significant number of publications, which together are equal to more than half of the entire sample. It can be noted (from the table below) that the journals in question are Sustainability, Journal of Cleaner Production, Technological Forecasting and Social Change, Social Enterprise Journal and Management Decision.

However, it is perceivable that the journals that are being analysed are strictly related to SDG 17 - PARTNERSHIP FOR THE GOALS and SDG 13 - CLIMATE CHANGE, SDG 9 - INDUSTRY, INNOVATION AND INFRASTRUCTURE and SDG 8 - DECENT WORK AND ECONOMIC GROWTH. 
Table 1. Journal publications-Most relevant sources

\begin{tabular}{ll}
\hline Sources & Articles \\
\hline SUSTAINABILITY & 111 \\
\hline JOURNAL OF CLEANER PRODUCTION & 51 \\
\hline TECHNOLOGICAL FORECASTING AND SOCIAL CHANGE & 25 \\
\hline SOCIAL ENTERPRISE JOURNAL & 24 \\
\hline MANAGEMENT DECISION & 21 \\
\hline ENTREPRENEURSHIP AND REGIONAL DEVELOPMENT & 20 \\
\hline MARKETING AND MANAGEMENT OF INNOVATIONS & 19 \\
\hline JOURNAL OF BUSINESS ETHICS & 17 \\
\hline BUSINESS STRATEGY AND THE ENVIRONMENT & 16 \\
\hline JOURNAL OF SOCIAL ENTREPRENEURSHIP & 14 \\
\hline JOURNAL OF KNOWLEDGE MANAGEMENT & 14 \\
\hline VOLUNTAS & 13 \\
\hline CIRIEC-ESPANA REVISTA DE ECONOMIA PUBLICA SOCIAL Y COOPERATIVA & 12 \\
\hline BALTIC JOURNAL OF ECONOMIC STUDIES & 12 \\
\hline CORPORATE SOCIAL RESPONSIBILITY AND ENVIRONMENTAL MANAGEMENT & 12 \\
\hline RESEARCH POLICY & 11 \\
\hline EUROPEAN PLANNING STUDIES & 11 \\
\hline INTERNATIONAL ENTREPRENEURSHIP AND MANAGEMENT JOURNAL & 11 \\
\hline INZINERINE EKONOMIKA-ENGINEERING ECONOMICS & 10 \\
\hline CHINESE MANAGEMENT STUDIES & 23 \\
\hline
\end{tabular}

Source: our elaboration

The sample is composed of 7280 authors. The authors with most impact so far have been:

LI Y (12), LI X (11), SCUOTTO (9), WANG L (9), ZHANG Y (9), EDGEMAN R (8), LI L (8), LIU Y (8), WANG J (8).

Checking the affiliation of the authors at the time of publication emerged that the most represented University are those represented on table 2 .

Most of the studies are the result of the work of a single author.

Table 2. Top 20 university for scientific production

\begin{tabular}{ll}
\hline Affiliations & Articles \\
\hline WUHAN UNIV TECHNOL & 30 \\
\hline BUCHAREST UNIV ECON STUDIES & 23 \\
\hline ZHEJIANG UNIV & 22 \\
\hline SCH MANAGEMENT & 20 \\
\hline UNIV MARIBOR & 17 \\
\hline UNIV TORONTO & 17 \\
\hline HARVARD UNIV & 16 \\
\hline LAPPEENRANTA UNIV TECHNOL & 16
\end{tabular}




\begin{tabular}{ll}
\hline UNIV MANCHESTER & 16 \\
\hline MIDDLESEX UNIV & 15 \\
\hline UNIV CAMBRIDGE & 15 \\
\hline WUHAN UNIV & 15 \\
\hline AARHUS UNIV & 14 \\
\hline HOHAI UNIV & 14 \\
\hline JIANGSU UNIV & 14 \\
\hline SUMY STATE UNIV & 14 \\
\hline TSINGHUA UNIV & 14 \\
\hline UNIV LEEDS & 14 \\
\hline CRACOW UNIV ECON & 13 \\
\hline HARBIN ENGN UNIV & 13
\end{tabular}

Source: our elaboration

The most cited countries, with more than 1000 citations are USA (10552), United Kingdom (4029), China (1801), Germany (1654), Italy (1239) and Canada (1147).

Strategic Management Journal has 3 papers on the first 20 articles in terms of citations, Harvard Business Review has 2 papers on the same list of top-cited papers.

The top 5 most cited sources are:

- $\quad$ Strategic management journal (2516)

- $\quad$ Academic management review (2380)

- $\quad$ Academic management journal (2056)

- Journal business of ethics (1832)

- $\quad$ Responsibility policy (1733)

Harvard Business review is on the $11^{\text {th }}$ position with 1094 citations.

Table 3. Top-cited documents

\begin{tabular}{|c|c|c|c|c|}
\hline Paper & Title & Journal - Book & $\begin{array}{l}\text { Total } \\
\text { Citations }\end{array}$ & $\begin{array}{l}\text { TC per } \\
\text { Year }\end{array}$ \\
\hline $\begin{array}{l}\text { TEECE DJ, 2007, } \\
\text { STRATEG MANAGE } \\
\text { J }\end{array}$ & $\begin{array}{l}\text { Explicating dynamic capabilities: the } \\
\text { nature and microfoundations of } \\
\text { (sustainable) enterprise performance }\end{array}$ & $\begin{array}{l}\text { Strategic } \\
\text { Journal } 28 \\
1319-1350,2007\end{array}$ & 3396 & 242,5714 \\
\hline $\begin{array}{l}\text { LEE C, 2001, } \\
\text { STRATEGIC } \\
\text { MANAGE J }\end{array}$ & $\begin{array}{l}\text { Internal capabilities, external networks, } \\
\text { and performance: a study on } \\
\text { technology-based ventures }\end{array}$ & \begin{tabular}{lcc} 
Strategic & \multicolumn{2}{c}{ management } \\
journal 22 & $\left(6^{-} 7\right)$, \\
$615-640$, & 2001
\end{tabular} & 900 & 45 \\
\hline $\begin{array}{l}\text { SHORT JC, 2009, } \\
\text { STRATEG ENTREP J }\end{array}$ & $\begin{array}{l}\text { Research in social entrepreneurship: past } \\
\text { contributions and future opportunities }\end{array}$ & $\begin{array}{l}\text { Strategic } \\
\text { entrepreneurship journal } \\
3(2), 161-194,2009\end{array}$ & 489 & 40,75 \\
\hline $\begin{array}{l}\text { HESS M, 2004, PROG } \\
\text { HUM GEOG }\end{array}$ & $\begin{array}{l}\text { Spatial" Relationships? Towards a } \\
\text { Reconceptualization of Embeddedness }\end{array}$ & $\begin{array}{l}\text { Progress in Human } \\
\text { Geography } \\
\text { 28(2):165-186, } 2004\end{array}$ & 474 & 27,8824 \\
\hline $\begin{array}{l}\text { BATTILANA J, 2014, } \\
\text { ACAD MANAG ANN }\end{array}$ & $\begin{array}{l}\text { Advancing Research on Hybrid } \\
\text { Organizing - Insights from the Study of } \\
\text { Social Enterprises }\end{array}$ & $\begin{array}{l}\text { The Academy of } \\
\text { Management Annals, } \\
\text { Volume } 8,2014 \text { Issue } 1\end{array}$ & 446 & 63,7143 \\
\hline
\end{tabular}




\begin{tabular}{|c|c|c|c|}
\hline $\begin{array}{ll}\text { DEES JG, } & 1998, \\
\text { HARVARD } & \text { BUS } \\
\text { REV } & \end{array}$ & Enterprising nonprofits & $\begin{array}{l}\text { Harv Bus Rev - Jan-Feb } 413 \\
\text { 1998; 76(1):54-67. }\end{array}$ & 17,9565 \\
\hline $\begin{array}{l}\text { LEE SY, 2004, REG } \\
\text { STUD }\end{array}$ & $\begin{array}{l}\text { Creativity and entrepreneurship: a } \\
\text { regional analysis of new firm formation }\end{array}$ & $\begin{array}{l}\text { Reg Stud 38(8): } 879-385 \\
\text { 891(book chapter), } 2004\end{array}$ & 22,6471 \\
\hline $\begin{array}{l}\text { CHAN YE，2007，J } \\
\text { INF TECHNOL-UK }\end{array}$ & t: what have we lea & $\begin{array}{l}\text { Journal of Information } 363 \\
\text { Technology } 22 \quad \text { (4): } \\
297-315 \text { (book chapter), } \\
2007\end{array}$ & 25,9286 \\
\hline
\end{tabular}

\begin{tabular}{lllllllll}
\hline HALL JK, 2010, J Sustainable development and Journal of Business 360 & 32,7273
\end{tabular}

BUS VENTURING entrepreneurship: Past contribution and Venturing, 2010

future decisions

\begin{tabular}{|c|c|c|c|}
\hline $\begin{array}{l}\text { BINKLEY M, 2012, } \\
\text { ASSESSMENT AND } \\
\text { TEACHING OF 21ST } \\
\text { CENTURY SKILLS }\end{array}$ & Defining Twenty-First Century Skills & 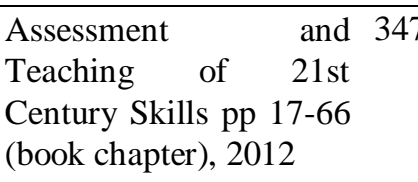 & 38,5556 \\
\hline $\begin{array}{l}\text { MELVILLE NP, 2010, } \\
\text { MIS QUART }\end{array}$ & $\begin{array}{l}\text { Information Systems Innovation for } \\
\text { Environmental Sustainability }\end{array}$ & MIS Quarterly, 2010 & 30,8182 \\
\hline $\begin{array}{l}\text { KLEWITZ J, 2014, J } \\
\text { CLEAN PROD }\end{array}$ & $\begin{array}{l}\text { Sustainability-Oriented } \\
\text { Innovation of SMEs: A Systematic } \\
\text { Review }\end{array}$ & $\begin{array}{l}\begin{array}{l}\text { Journal of } \\
\text { Production } \\
2014\end{array} \\
65: 57-75,\end{array}$ & 47,7143 \\
\hline
\end{tabular}

THORPE R, 2005, Using Knowledge within Small and International Journal of $312 \quad 19,5$

INT J MANAG REV Medium-Sized Firms: A Systematic Management Reviews

Review of the Evidence 7(4), 2005

STRAUB DW, 1994, The effect of culture on IT diffusion: Information Systems $303 \quad 11,2222$

INFORM SYST RES E-mail and FAX in Japan and the U.S Research 5(1):23-47,

1994

SCHNEIDER MR, Mapping the institutional capital of Journal of International $243 \quad 22,0909$

2010, J INT BUS high-tech firms: A fuzzy-set analysis of Business Studies, 2010,

STUD capitalist variety and export performance vol. 41, issue 2, 246-266

HANSEN MT, 2004, How do multinational companies Strategic Management $216 \quad 12,7059$

STRATEGIC leverage technological competencies? Journal 25 (8-9),

MANAGE J Moving from single to interdependent 801-822, 2004

explanations

COOKE P, 1999, Small Firms, Social Capital and the Small Business 203 9,2273

SMALL BUS ECON Enhancement of Business Performance Economics volume 13,

Through Innovation Programmes pages219-234, 1999

KANTER RM, 1999, The Enduring Skills of Change Leaders $\quad$ Harvard $\quad$ Business $200 \quad 9,0909$

HARVARD BUS Review - Leader to

REV

Leader 13 (summer

1999)

\begin{tabular}{|c|c|c|c|}
\hline $\begin{array}{l}\text { BATTILANA J, 2015, } \\
\text { ACAD MANAGE J }\end{array}$ & $\begin{array}{l}\text { Harnessing productive tensions in hybrid } \\
\text { organizations: The case of work } \\
\text { integration social enterprises }\end{array}$ & $\begin{array}{lr}\text { Academy } & \text { of } 189 \\
\text { Management } & \text { Journal, } \\
2015 & \end{array}$ & 31,5 \\
\hline $\begin{array}{lrl}\text { JENKINS } & \mathrm{H}, & 2009, \\
\text { BUS ETHICS } & \end{array}$ & $\begin{array}{l}\text { A Business Opportunity Model of } \\
\text { Corporate Social Responsibility for } \\
\text { Small- and Medium-Sized Enterprises }\end{array}$ & $\begin{array}{l}\text { Business Ethics A } 186 \\
\text { European Review 18(1), } \\
2009\end{array}$ & 11 \\
\hline
\end{tabular}

Source: our elaboration 
In the most cited articles, the most relevant scientific contribution are:

- (Teece 2007), which observes that "Enterprises with strong dynamic capabilities are intensely entrepreneurial. They not only adapt to business ecosystems, but also shape them through innovation and through collaboration with other enterprises, entities, and institutions.";

- (Lee, Lee, e Pennings 2001), that examines "the influence of internal capabilities and external networks on firm performance by using data from 137 Korean technological start-up companies";

- (Short, Moss, e Lumpkin 2009) is a literature review that assumes that in the particular field of social enterprises there is "often lack formal hypotheses and rigorous methods" and that "social entrepreneurship is informed by common areas of interest (...) like entrepreneurship, public/nonprofit management, and social issues, all of which represent fruitful venues for future research efforts";

- (Hess 2016), that examines the concept of embeddedness in economic geography.

\subsection{Keyword Co-occurrences Network}

Every article published must contain keywords. These keywords are the research fields that have been involved in the respective articles. It establishes the co-occurrences of the network keywords. The purpose of the co-occurrence analysis is to design the conceptual structure of a frame of reference using a network of co-occurrence words to map and group the terms extracted from the keywords into a bibliographic collection. The following figure 3 provides information to find out which fields have been linked to social enterprises research. The figure shows that researchers combine their scientific production with a more significant number of keywords. It shows, therefore, that from the current elaboration, a clear perception of how a central the role is played by INNOVATION, PERFORMANCE and MANAGEMENT.

In addition, the most involved keywords are ENTREPRENEURSHIP, IMPACT, KNOWLEDGE, MODEL, ENTERPRISE, NETWORKS, FIRMS.

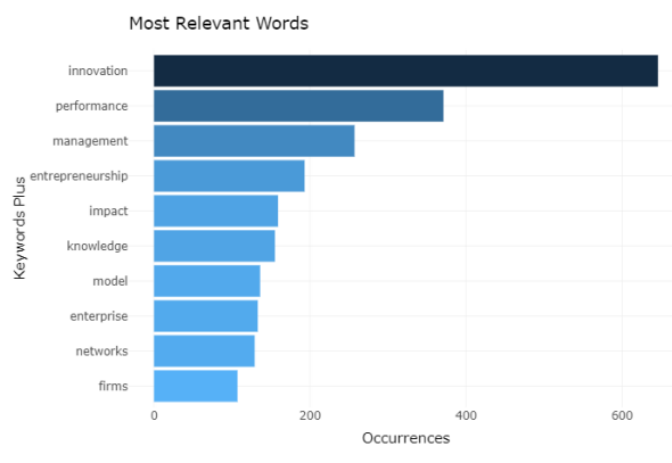

Figure 3. Most relevant word

Source: our elaboration

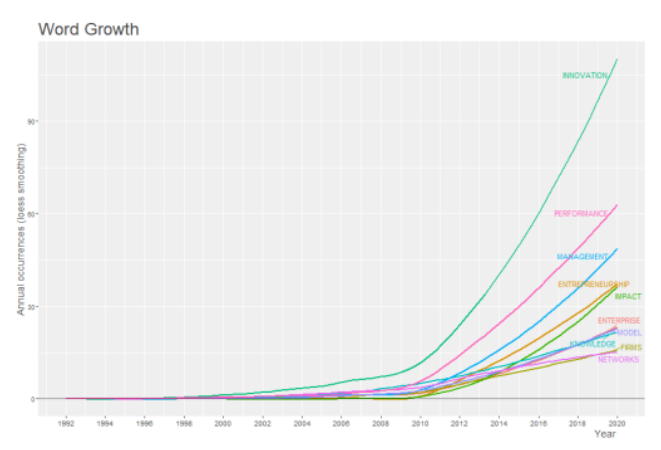

Figure 4. Annual occurrences of most cited words

Source: our elaboration 
The figure above helps to understand the incredible spread of the annual occurrences of the most cited words in the last 30 years. This selection of keywords allows us to understand that, in addition to management and performance, the most relevant topic is those that dealt with in SDG 9: INNOVATION. In fact, looking at this selection of keywords, the reference to SDG objective 9 "industry, innovation and infrastructure", which aims to ensure the building of resilient infrastructure promotion of inclusive and sustainable industrialization and fostering innovation, appears more pronounced than ever, in addition to the keywords "ENTERPRISE", "KNOWLEDGE" and "IMPACT", particularly after 2015 .

Another important reference is to SDG objective 17 "partnership for the goals", which sets the goal of strengthen the means of implementation and revitalize the global partnership for sustainable development where the main keyword is "NETWORK ".

The US keyword is due to the predominance in scientific publications of US scholars.

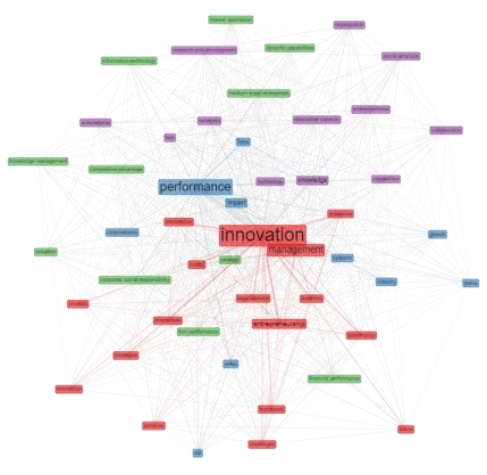

Figure 5. Keyword co-occurrences network

Source: our elaboration

\subsection{Coding Keyword}

To examine the content of the articles, the study develops a list of the main keywords divided for each SDG and identified according to the keywords of each objective. The objective of the coding process is to determine whether there is a match between the SDG keywords and the keywords in the article collection, which is composed of a large number (2433) associated with the articles by the authors and databases.

A list of all keywords has been compiled by grouping them and associating them to each SDG (see Appendix 1) of reference. This also generated a final list of keywords that could not be grouped and had been removed from the coding process (Furrer, Thomas, e Goussevskaia 2008). Previous studies of journal content have generally classified articles in only one main category (Bingham e Bowen, 1994); (Helgeson et al., 1984); (Inkpen e Beamish, 1994); Yale e Gilly, 1988). However, as noted by Inkpen and Beamish in 1994 (Keesstra, Bouma, Wallinga, Tittonell, Smith, Cerdà, Montanarella, Quinton, Pachepsky, van der Putten, et al. 2016), the use of a single category does not recognize the cross-functional and interdisciplinary nature of an academic field as in the case of SDGs (Ferlie e Ongaro 2015). Therefore, we decided to assign the articles to one or more keywords.

It was possible to code 2433 keywords, based on the reference SDGs.

Based on the keyword encoding activity, it emerges that the social enterprises literature deals with 16 SDGs out of 17 SDGs, particularly SDG 17 - PARTNERSHIP FOR THE GOALS and SDG 13 - CLIMATE CHANGE, SDG 9 INDUSTRY, INNOVATION AND INFRASTRUCTURE and SDG 8 - DECENT WORK AND ECONOMIC GROWTH.

SDG 10 - REDUCTION OF REDUCED INQUALITY does not match with the considered literature.

Figure 6 below summarizes the coding activity. It is the result of the coding activity found in Appendix 1. The graph illustrates how many keywords are associated with each SDG. The chart demonstrates the prevalence in the scientific treatment of SDG 17, 13, 9 and 8. 


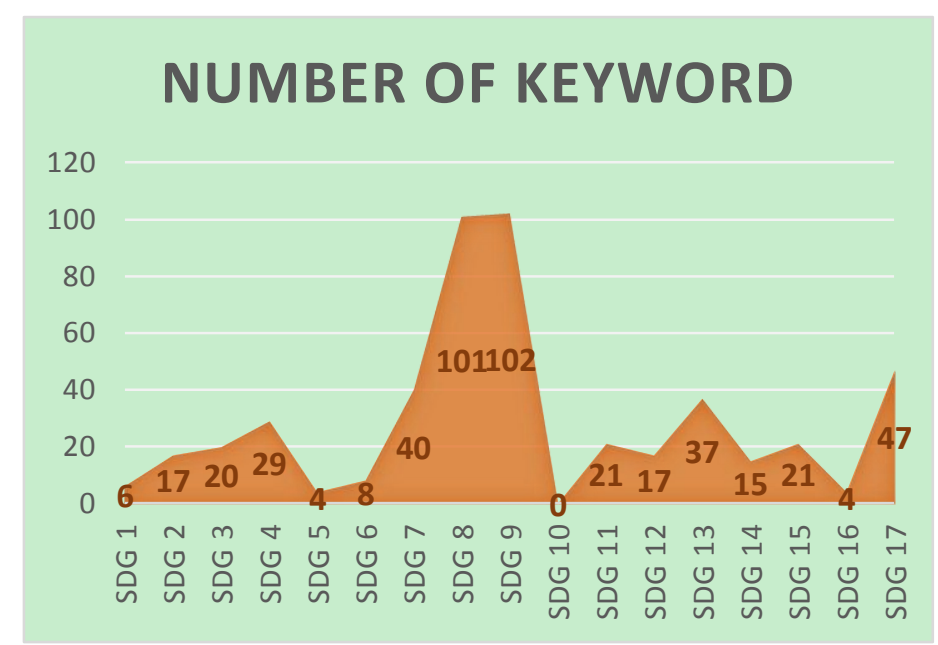

Figure 6. Coding keyword summary

Source: our elaboration

\section{Discussion and Conclusions}

\subsection{Contributions to the Literature}

In order to develop a sustainable approach to international growth, social enterprises must continue to learn from experience and adapt during their internationalization and connect all stakeholders with innovative reporting tools.

This paper argued that although there is no explicit reference to the SDGs in social enterprise journals, the issues are widely covered and are part of the scientific debate in the specific field.

The study presents the results of 30 years of research in the field of social enterprises and an overview of the contribution of social enterprises to achieving global goals. Although the SDGs were only issued in 2015, the topics they address are variously present throughout the timeline and can be read in the bibliometric analysis. A bibliometric method was used to analyze the characteristics, citation patterns, and content of 3318 documents published in international academic journals, book and chapter reviews, editorial materials, and proceedings papers. By adopting this scientific method, the analysis presents a deeper understanding of the intellectual structure of the social enterprise field by interpreting the study's emergent bibliometric characteristics designed to map and understand the current maturity of the fields. However, the main finding is that the keywords used in articles related to social enterprises and innovation relate to those types of several SDGs. In the sample, even though the SDGs are not explicitly mentioned, the topics covered are typical of this field. Regarding the SDGs, we noticed that the topics covered are typical of publications in journals related to social enterprises. The only exception was SDG 10 REDUCED INEQUALITIES, which is not mentioned at all.

The following SDG areas are also not very well covered: SDG 1 - NO POVERTY, SDG 5 - GENDER EQUALITY, and SDG 6 - CLEAN WATER AND SANITATION.

In the research, there is a sense of the multidisciplinary nature of the topic and how the literature has treated it consistently. Because it is an interdisciplinary field, it benefits from a number of increased intersections with emerging approaches that also lead to practical feedback.

The bibliometric analysis showed that there are journals that have had a greater output on the topic with a significant impact on research. The case study is the most used method to demonstrate the centrality of social enterprises in social innovation, as it emerges from the analysis of the studies of the most impactful authors. The analysis also shows that the centrality of the themes is related to innovation, impact, management, and performance, demonstrating the hypothesis that the driver of innovation in terms of social impact is given by these types of enterprises.

The results also highlight that there is a rise in publications on the topic since they were included in the global background The 17 Sustainable Development Goals that make up the 2030 Agenda refer to different areas of social, economic, and environmental development, we refer to the year 2015. 
This brings out how impactful is the graft of global organizations to provide a direction of innovation in terms of social impact.

\subsection{Implications for Managers}

Based on the study's preliminary evidence and if supported by further research, social enterprise decision-makers can improve the effects of their actions internally and externally, even when reflection on best practices is not perceived as urgent.

Since it is commonly accepted that innovation is the theme of social enterprises par excellence and because it generates growth, we find that this aspect was particularly evident. However, at present, in the subject of the publication of the analysis, issues regarding network and performance are still important. At a time when the crisis has created great difficulties for the system, it is very important to understand what the model is for creating impact through companies. In turn, they can create a cycle of ethical investments through a chain reaction that generates activities capable of creating social impact by helping citizens in need.

The results suggest that these micro-processes can be supported by an entrepreneurial attitude that allows business managers to regularly take stock and be ready to act quickly by being aware of their company's financial and non-financial data, especially in a language that is certainly accessible. Too often, smaller companies going to market don't have the time or resources to make these assessments, and this can lead to inefficiencies that last longer than necessary, resulting in wasted resources and poor returns, as well as reducing opportunities for learning and adapting practices.

In the specific context, best practices that are around the topic of social impact consist of using human capital with increasingly specific combinations of skills and know-how. The manager must select the human capital to carry out these activities, otherwise, he or she will have to provide external professionals for implementation.

\subsection{Limitations and Future Research}

The study shows a limitation, related to the adoption of the bibliometric method even as it considers books, chapters, articles published in international and academic journals, editorial materials, reviews, and proceedings papers.

The purpose of our exploratory study is to provide insights that other scholars can draw upon and explore further in the process of theory development. Therefore, this study invites scholars to investigate the transferability of our insights and provides several promising avenues for future research.

These findings suggest that in general, the SDGs are the cataloging and organizing of topics that are already present and thus can be found in articles by social actors published over the past 30 years. In fact, interest in the SDGs and social enterprises has continually grown especially in the last 5 . These findings form the basis for providing support to the scientific research sector, third sector agents, investors, and all stakeholders working with social entrepreneurs to better understand the focus on which research and social enterprises will need to concentrate in order to generate social impact. First, researchers question whether the social impact focus can generate transparency and accountability applied to all nonprofit but also for-profit contexts, as the current literature provides us with additional distinctions in this category: for impact and without impact (Calderini et al., 2018; Clark et al., 2004; Meneguzzo, 2005).

Second, the results highlight that this study is an opportunity to direct future research to fill gaps in the literature. Since the SDGs are goals to be achieved by 2030 (2030 AGENDA), evidence of these gaps can raise awareness of the scientific output and thus facilitate the achievement of the goals. In this sense, the literature places social enterprises at the center of social innovation by focusing on performance and management issues.

Third, to reach more general conclusions, the 2030 goals toward which the world is racing seem to be set by large institutions and public bodies. Social enterprises, which are the drivers of social impact, can certainly contribute to this, and trying to provide a dashboard of the SDGs business format can help generate global development from the local.

It would be very interesting to spark further empirical studies investigating the impact on tools related to the focus of this work. Generating social impact creates a need for reporting on this data and therefore the identification of good reporting tools on the global goals that humanity must now aim for.

In conclusion, with the aim of demonstrating how social enterprise contributes to the achievement of sustainable goals and crystallizing academic studies on this field and furthermore to demonstrate the evolution of the perception of social enterprises in the literature. This research shows how, over 30 years, the literature has placed social enterprises at the center of social innovation by focusing on performance and management issues. 
The research confirms that social enterprises play a central role on the topic of the innovation-oriented social impact of the whole ecosystem. This condition increases accountability, transparency, and stakeholder engagement. Stakeholders would be able to better understand the strong values of the company itself and all the partnerships that are normally created to be able to achieve the goals, in line with SDG 17.

To define the field of innovation and identify the social value of the company, which is returned to the ecosystem of the territory, it is important and useful to define the business model as a tool that can facilitate (or not) the diffusion of innovation in the system. The value inherent in innovation remains latent until it is placed on the market or otherwise made explicit and this can only happen through the use of a business model (Chesbrough and Rosenbloom, 2002). Through the research project conducted so far, it has been possible to demonstrate that in social enterprises, in order to have an effective measurement of impact, it is necessary to use all possible tools to know and describe the company and the ecosystem that surrounds it, and this is possible through timely reporting that provides clear information for everyone.

\section{References}

Arnold, V., Koenraad, D., Luwel, M., \& Zimmermann, E. (2002a). Measuring progress and evolution in science and technology - i: the multiple uses of bibliometric indicators. International Journal of Management Reviews, 4(2), 179-211. https://doi.org/10.1111/1468-2370.00083

Calderini, M., Chiodo, V., \& Michelucci, F. V. (2018). The social impact investment race: toward an interpretative framework. Eur. Bus. Rev., 30, 66-81.

Carlo, B. (2002). Sull'impresa sociale. ISSAN Working Papers, (19).

Carlo, B., \& Tortia, E. (2004). Dalla cooperazione mutualistica alla cooperazione sociale. Impr. Soc, 4, 44.

Chesbrough, H., \& Rosenbloom, R. S. (2002). The role of the business model in capturing value from innovation: evidence from Xerox Corporation's technology spin-off companies. Ind. Corp. Change, 11, 529-555.

Chitu, O., \& Schabram, K. (2010a). A guide to conducting a systematic literature review of information systems research. SSRN Electronic Journal Sprouts: Working Papers on Information Systems. https://doi.org/10.2139/ssrn.1954824

Choonwoo, L., Lee, K., \& Pennings, J. M. (2001). Internal capabilities, external networks, and performance: a study on technology-based ventures. Strategic Management Journal, 22(6-7), 615-640. https://doi.org/10.1002/smj.181

Clark, C., Rosenzweig, W., Long, D., \& Olsen, S. (2004). Double bottom line project report: assessing social impact in double bottom line ventures.

David, L., \& Holt, D. (2018). Social enterprise resilience in sub-saharan Africa. Business Strategy \& Development, l(1), 53-63. https://doi.org/10.1002/bsd2.11

Ewan, F., \& Ongaro, E. (2015). Strategic management in public services organizations: Concepts, schools and contemporary issues. Routledge.

Francesca, C., Teasdale, S., Donaldson, C., Michael, J. R., \& Baglioni, S. (2018). Collaborator or competitor: assessing the evidence supporting the role of social enterprise in health and social care. Public Management Review, 20(12), 1790-1814.

Francesco, B. (2000). Finanza etica e impresa sociale: $i$ valori come fattori competitivi. Il mulino.

Furrer Et Al 2008 Ijmr-libre, Strategic Management, \& Cognitive Science. (2020). Scribd. Consultato 5 aprile 2020. Retrieved from https://www.scribd.com/document/213659880/Furrer-Et-Al-2008-Ijmr-libre

Geert, B., Loretan, R., \& Troupin, S. (2016). Public administration and the sustainable development goals.

Gloria, F., Jannelli, R., \& Meneguzzo, M. (2012). CSR 2.0 proattiva e sostenibile: tra mercati globali e gestione della crisi. EGEA spa.

Goldoff, A. C. (2000). Decision-making in organizations: the new paradigm. International Journal of Public Administration, 23(11), 2017-2044.

Jane, F., Hill, C., \& Muñoz, S.-A. (2012). Community co-production: social enterprise in remote and rural communities. Edward Elgar Publishing.

Joyce, P. (2015, November). Ewan ferlie and edoardo ongaro, strategic management in public services organizations: concepts, schools and contemporary issues. Local Government Studies, 1-3. 
https://doi.org/10.1080/03003930.2015.1103548

Keesstra, S. D., Bouma, J., Wallinga, J., Tittonell, P., Smith, P., Cerdà, A., et al.. (2016). The significance of soils and soil science towards realization of the united nations sustainable development goals. SOIL, 2(2), 111-128. https://doi.org/10.5194/soil-2-111-2016

Li, W., \& Yang, Zh. (2015b). Bibliometric analysis of global environmental assessment research in a 20 -year period. Environmental Impact Assessment Review, 50(gennaio), 158-166. https://doi.org/10.1016/j.eiar.2014.09.012

Ma, Y., Ming, D., Zhou, K. H., Mita, C., Liu, J. P., \& Wayne, P. M. (2016a). Publication trends in acupuncture research: a 20-year bibliometric analysis based on PubMed. PloS One, 11(12). https://doi.org/10.1371/journal.pone.0168123

Martin, H. (2016). 'Spatial' relationships? Towards a reconceptualization of embedded ness: progress in human geography. luglio. https://doi.org/10.1191/0309132504ph479oa

Massimo, A., \& Cuccurullo, C. (2017). Bibliometrix: An r-tool for comprehensive science mapping analysis. Journal of Informetrics, 11(4), 959-975. https://doi.org/10.1016/j.joi.2017.08.007

Meneguzzo, M. (2005). Creazione di valore e sviluppo del capitale sociale. Rivista italiana di ragioneria e di economia aziendale.

Michele, M., Musella, M., \& Pastore, F. (2007). Relational goods, monitoring and non-pecuniary compensations in the nonprofit sector: the case of the Italian social services. Annals of Public and Cooperative Economics, 78(1), 57-86.

Michele-Lee, M., Westley, F. R., \& Brodhead, T. (2012). Social finance intermediaries and social innovation. Journal of Social Entrepreneurship, 3(2), 184-205.

Michele-Lee, M., Westley, F. R., \& Nicholls, A. (2012). The social finance and social innovation nexus. Taylor \& Francis.

Olivier, F., Thomas, H., \& Goussevskaia, A. (2008). The structure and evolution of the strategic management field: A content analysis of 26 years of strategic management research - Furrer - 2008. International Journal of Management Reviews. Wiley Online Library. Retrieved from https://onlinelibrary.wiley.com/doi/full/10.1111/j.1468-2370.2007.00217.x?casa_token=NVuSB8dyRaYAAAA A\%3A_7brGQRwo8Vxz-zl5wozjD6ijgcRUDig2KHKOUzLiSqL04fNq64A4Ps33-3SEng2vQCS4qxym11h7xk $\mathrm{POg}$

Paolo, B., Secinaro, S., Brescia, V., \& Iannaci, D. (2018). Popular financial reporting, a new information tool for social cooperatives.

Paolo, B., Secinaro, S., Brescia, V., \& Iannaci, D. (2019a). La misurazione dell'impatto sociale nelle organizzazioni ibride. In XIII edizione del Colloquio Scientifico sull'impresa sociale di Roma Tor Vergata (Vol. 13, pp. 1-31).

Paolo, B., Secinaro, S., Brescia, V., \& Iannaci, D. (2019b). The popular financial reporting between theory and evidence.

Pietro, B. P., \& Radwan, M. (2019). Social finance and financing social enterprises: an Islamic finance prospective. European Journal of Islamic Finance.

Quinn, P. M. (1999). Enhancing the quality and credibility of qualitative analysis. Health services research, 34(5Pt2), 1189.

Rehn, A. (2008). Pop (culture) goes the organization: On highbrow, lowbrow and hybrids in studying popular culture within organization studies. Organization, 15(5), 765-783.

Rey-Martí, A., Domingo, R.-S., \& Daniel, P.-M. (2015). A bibliometric analysis of social entrepreneurship. Journal of Business Research, 69(5), 1651-1655. https://doi.org/10.1016/j.jbusres.2015.10.033

Richard, W. (2000a). The intellectual and social organization of the sciences. Oxford University Press on Demand.

Richard, W. (2000b, September). The institutional structuring of innovation strategies: business systems, firm types and patterns of technical change in different market economies. Organization Studies - Organ Stud, 21, 855-886. https://doi.org/10.1177/0170840600215002

Ruben, H., Cubillo, L. D. L. T., Galan, D., Cabrerizo, F., Herrera-Viedma, E., \& Dormido, S. (2016). Virtual and remote labs in education: a bibliometric analysis. Computers \& Education, 98(luglio), 14-38. 
https://doi.org/10.1016/j.compedu.2016.03.010

Ruben, H., Perez-Morago, H., Fernandez-Amoros, D., Cabrerizo, F. J., \& Herrera-Viedma, E. (2016, April). A bibliometric analysis of 20 years of research on software product lines. Information and Software Technology, 72, 1-15. https://doi.org/10.1016/j.infsof.2015.11.004

Short, J. C., Todd, W. M., \& Lumpkin, G. T. (2009). Research in social entrepreneurship: past contributions and future opportunities. Strategic Entrepreneurship Journal, 3(2), 161-194. https://doi.org/10.1002/sej.69

Silvana, S., Corvo, L., Brescia, V., \& Iannaci, D. (2019). Hybrid organizations: a systematic review of the current literature. International Business Research, 12(11), 1-21.

Stefano, Z., Venturi, P., \& Rago, S. (2015). Valutare l'impatto sociale. La questione della misurazione nelle imprese sociali. Impresa Soc, 6, 77-97.

Teece, D. J. (2007). Explicating dynamic capabilities: the nature and microfoundations of (sustainable) enterprise performance. Strategic Management Journal, 28(13), 1319-1350. https://doi.org/10.1002/smj.640

Veronica, G., Colasanti, N., Frondizi, R., \& Barreca, M. (2018). Civic crowdfunding, social marketing and the co-creation of public value. Mercati \& Competitività.

Villiers, C. (2019). The influence of Integrated Reporting and stakeholder information needs on the disclosure of social information in a state-owned enterprise. Meditari Accountancy Research, forthcoming, marzo.

Wallis, M., Dini, P., \& Sartori, L. (2017). Self-Funded social impact investment: An interdisciplinary analysis of the Sardex mutual credit system. Journal of Social Entrepreneurship, 8(2), 149-164.

Webster, J., \& Watson, R. (2002a). Analyzing the past to prepare for the future: writing a literature review. MIS Quarterly, 26(giugno). https://doi.org/10.2307/4132319

\section{Copyrights}

Copyright for this article is retained by the author(s), with first publication rights granted to the journal.

This is an open-access article distributed under the terms and conditions of the Creative Commons Attribution license (http://creativecommons.org/licenses/by/4.0/). 